\title{
Evaluation of the effect of D-amino acid incorporation into amyloid-reactive peptides
}

\author{
Emily B. Martin ${ }^{1 *}$, Angela Williams ${ }^{1}$, Tina Richey ${ }^{1}$, Craig Wooliver ${ }^{1}$, Alan Stuckey ${ }^{2}$, James S. Foster ${ }^{1}$,
} Stephen J. Kennel ${ }^{1,2}$ and Jonathan S. Wall ${ }^{1,2}$

\begin{abstract}
Background: Systemic amyloidoses comprise diseases characterized by the deposition of proteinaceous material known as amyloid. Currently, without performing multiple biopsies, there is no way to ascertain the extent of amyloid deposition in patients - a critical piece of information that informs prognosis and therapeutic strategies. We have developed pan-amyloid-targeting peptides for imaging amyloid and recently have adapted these for use as pretargeting agents in conjunction with immunotherapy. Incorporation of D-amino acids in these peptides may enhance serum half-life, which is an important characteristic of effective peptide therapeutics. Herein, we assess the effects of partial incorporation of D-amino acids into the amyloidophilic peptide 55 on in vivo amyloid reactivity.

Methods: Peptides, referred to as ${ }^{\mathrm{AQA}}{ }^{\mathrm{p} 5}$ (D)' $^{\text {aqa }} \mathrm{p5}$, and ${ }^{\mathrm{AQA}} \mathrm{p5}$, were radiolabeled with iodine-125 and the tissue biodistribution (\% injected dose/gram) measured in healthy mice at multiple time points post-injection. Microscopic distribution of the peptides was further visualized using microautoradiography (ARG). Peptides ${ }^{\text {aqa }} \mathrm{p} 5$ and ${ }^{\mathrm{AQA}} \mathrm{p} 5$ were injected into healthy and amyloid-laden mice and evaluated by using SPECT/CT imaging at 1,4 and $24 \mathrm{~h}$ post injection.
\end{abstract}

Results: Biodistribution data and ARG revealed persistent retention of $\left[{ }^{125} \mathrm{I}\right]^{\mathrm{AQA}} \mathrm{p} 5_{(0)}$ in the liver and kidneys of healthy mice for at least $24 \mathrm{~h}$. In contrast, peptides $\left[{ }^{125} \mid\right]^{\text {aqa }} \mathrm{p} 5$ and $\left[{ }^{125}\right]^{\mathrm{AQA}} \mathrm{p} 5$ did not bind these organs and was significantly lower than $\left[{ }^{125} \mathrm{I}\right]^{\mathrm{AQA}} \mathrm{p} 5_{(\mathrm{D})}$ at $24 \mathrm{~h}$ post injection $(\mathrm{p}<0.0001)$. SPECT/CT imaging of amyloid-laden mice revealed accumulation of both $\left[{ }^{125} \mathrm{I}\right]^{\mathrm{aqa}} \mathrm{p} 5$ and $\left[{ }^{125} \mid\right]^{\mathrm{AQA}} \mathrm{p} 5$ in amyloid-affected organs; whereas, in healthy mice, $\left[{ }^{125} \mathrm{l}\right]^{\mathrm{aqa}} \mathrm{p} 5$ was observed in the kidneys and liver at early time points, and free radioiodide liberated during catabolism of $\left[{ }^{125}\right]^{\mathrm{AQA}} \mathrm{p} 5$ was seen in the stomach and thyroid. Autoradiography confirmed that both $\left[{ }^{125} \mid\right]^{\text {aqa }} \mathrm{p} 5$ and $\left[{ }^{125} \mathrm{l}\right]^{\mathrm{AQA}} \mathrm{p} 5$ peptides specifically bound amyloid with no off-target binding to healthy organs.

Conclusion: Incorporation of D-amino acids in amyloid-binding regions of amyloidophilic peptides resulted in off-target binding; however, $\mathrm{N}$-terminus placement retained amyloid-specificity and evasion of deiodinases. Peptide aqa 5 , or similar reagents, may prove useful in novel immunotherapy strategies as well as for imaging renal, gastric and pancreatic amyloidosis.

Keywords: Amyloidosis, Peptides, p5, D-Amino acids, Imaging, Dehalogenation

\section{Background}

The systemic amyloidoses are a group of diseases that result in the accumulation of misfolded proteins as fibrils in various organs and tissues. To date, more than 35 different proteins have been identified as fibrillar

\footnotetext{
${ }^{*}$ Correspondence: emartin@utmck.edu

${ }^{1}$ Department of Medicine, University of Tennessee Medical Center, 1924

Alcoa Hwy, Knoxville, TN 37920, USA

Full list of author information is available at the end of the article
}

components of amyloid deposits in man [1-3]. In addition to protein fibrils, amyloid deposits also invariably contain hypersulfated heparan sulfate proteoglycans (HSPG) and serum proteins, notably serum amyloid P component, which are pathognomonic features of these diseases [3, 4]. In systemic forms of amyloidosis, any or all abdominothoracic organs or tissues can be involved; however, the liver, spleen, nerves, intestines, kidneys and heart are most common, and the relentless accumulation 
of tissue amyloid contributes to morbidity and mortality [5].

Amyloid patients often present with diverse symptomology and varied patterns of organ involvement; thus, accurate and rapid diagnosis is difficult, and the prognosis and treatment options depend on the affected organs and the extent of amyloid load [5, 6]. Given the clinical heterogeneity of these diseases, it is important to discern the amyloid burden and organ involvement in each patient such that appropriate therapies can be administered. Currently, there are no methods, in the US, to quantitatively assess whole-body amyloid load in patients with the many diverse types of systemic amyloidosis other than obtaining biopsies from every tissue-an invasive, potentially dangerous, impractical approach that is prone to sampling error. Of the clinically available amyloid-targeting imaging agents, none is capable of detecting all types of amyloid in all organs. For example, the use of technetium-99 m-labeled bone-seeking agents is limited only to cardiac transthyretin-associated amyloidosis [7]. Thus, there is an unmet clinical need for an imaging agent capable of detecting many, if not all, types of systemic amyloid regardless of the anatomic site of deposition. For this reason, our recent efforts have focused on developing an imaging agent for the non-invasive, quantitative assessment of amyloid load in patients [8-10].

To this end, we have developed synthetic, polybasic, amyloid-reactive peptides to serve as pan-amyloid imaging agents [8-12]. Since hypersulfated HSPG and protein fibrils-both linear arrays of charged components-are ubiquitously present in all amyloid fibrils, we designed polybasic peptides, which have been shown to bind specifically to amyloid via electrostatic components. One of the most highly characterized of these peptides, known as $55[8,12]$, is composed of 31 amino acids containing 4 amyloid-binding heptad repeats and a short leader sequence. Peptide $\mathrm{p} 5$, and related peptides, bind diverse forms of human amyloid extract and amyloid-like fibrils in vitro [11], and when radiolabeled via iodotyrosine, they have been shown to specifically bind systemic serum amyloid protein A-associated (AA) amyloid deposits in mice [8-12]. Recently, we have expanded the utility of the peptides as the basis of novel immunotherapy strategies, and peptides with an extended serum and targetbound half-life are desirable properties in our therapeutic agents. Consequently, we have explored different peptide structures containing $\mathrm{D}$-amino acids that may confer increased serum half-life and provide resistance to dehalogenation of the iodotyrosine. The analog of $\mathrm{p} 5$ containing all $\mathrm{D}$-amino acids, $\mathrm{p} 5_{(\mathrm{D})}$, adopts an $\alpha$-helical secondary structure and exhibited amyloid binding properties in vitro comparable to p5. However, when $\mathrm{p} 5$ (D) was radiolabeled and injected into amyloid-free mice, the peptide exhibited unexpected off-target binding, notably in the kidney and liver [10].

To further probe the effects of incorporating D-amino acids in amyloid-reactive peptides, we now describe studies of three variants that have been modeled after the 31-amino acid parent peptide, p5. The peptides evaluated in this study, designated ${ }^{\mathrm{AQA}} \mathrm{p} 5(\mathrm{D}),{ }^{\mathrm{aqa}} \mathrm{p} 5$ and ${ }^{\mathrm{AQA}} \mathrm{p} 5$, contain modified $\mathrm{N}$-terminal amino acids, relative to the $\mathrm{p} 5$ peptide, to allow incorporation and evaluation of D-amino acids. These peptides, when radioiodinated, exhibited distinct biodistribution and dehalogenation propensity in healthy mice. The ${ }^{\mathrm{AQA}} \mathrm{p} 5_{(\mathrm{D})}$ variant, with D-amino acids in the amyloid-reactive site, bound intensely to tubules in the renal cortex and throughout the liver of amyloid-free mice; whereas, peptide ${ }^{\text {aqa }} \mathrm{p} 5$, with the incorporation of only three D-amino acids at the $\mathrm{N}$-terminus, retained specific amyloid reactivity in vivo and prevented dehalogenation of the juxtaposed L-iodotyrosine. This allowed precise and accurate determination of the peptide's tissue biodistribution without the complication of the loss of iodine- 125 from the radiotracer. This peptide, ${ }^{\text {aqa }} \mathrm{p} 5$, was shown to specifically bind AA amyloid deposits in mice and did not exhibit offtarget reactivity in the liver or kidney. The importance of D-amino acid placement in amyloid-reactive peptides that may have utility in novel therapeutic paradigms or as imaging agents is discussed.

\section{Methods \\ Peptide preparation}

Peptides ${ }^{\mathrm{AQA}} \mathrm{p} 55_{(\mathrm{D})},{ }^{\mathrm{aqa}} \mathrm{p} 5$ and ${ }^{\mathrm{AQA}} \mathrm{p} 5$ (Table 1) were purchased from Anaspec (Fremont, CA) as crude preparations and were purified by reverse-phase high performance liquid chromatography (RP-HPLC; Biologic DuoFlow; BioRad, Hercules, CA) using a C3 matrix (ZorbaxTM 300SB; Agilent, Santa Clara, CA). A linear gradient of $1-51 \%$ acetonitrile in water with $0.05 \% \mathrm{v} / \mathrm{v}$ trifluoroacetic acid served as the mobile phase. A flow rate of $4 \mathrm{~mL} / \mathrm{min}$ was used to elute the peptides. Fractions were collected, pooled, and integrity of the peptides was verified by mass spectrometry $[9,10]$. Analytical HPLC was performed, essentially as described above, but using a Zorbax SB-C3 $1500 \mathrm{~mm}$ matrix with a flow rate of $1 \mathrm{~mL} / \mathrm{min}$.

\section{Table 1 Primary structure of peptides}

\begin{tabular}{ll}
\hline Peptide & Primary structure \\
\hline${ }^{A Q A}{ }^{2} 5(D)$ & AQAys kaqka qakqa kqaqk aqkaq akqak q \\
${ }^{a q a} 55$ & aqaYS KAQKA QAKQA KQAQK AQKAQ AKQAK Q \\
${ }^{A Q A}$ p5 & AQAYS KAQKA QAKQA KQAQK AQKAQ AKQAK Q
\end{tabular}

D-Amino acids are shown in lower case 


\section{Circular dichroism}

CD spectra were obtained for all peptides $(0.05 \mathrm{mg} / \mathrm{mL}$ in PBS) using a DSM 1000 CD instrument (Olis Inc., Bogart, Georgia) with a peptide sample volume of $2.9 \mathrm{~mL}$ and a $1 \mathrm{~cm}$ cuvette path length. Data were collected in triplicate over the 190-250 nm wavelength range with $1 \mathrm{~nm}$ increments. Increasing amounts of low molecular weight heparin (Enoxaparin sodium, Sanofi, Bridgewater, NJ) up to $1.5 \mathrm{mg}$ was added to each peptide to induce secondary structure transitions. All data were corrected for background by subtraction of a PBS or PBS with enoxaparin CD spectrum. Mean residue ellipticity $[\Theta]$ was calculated according to: $\Theta *(\mathrm{MW} /$ no. AA $) /(10$ *conc. *l) where: $\Theta$ is ellipticity (millidegrees); MW is the molecular weight of the peptide (3356.8 Da); no. AA, is the number of amino acid residues, (31); conc. is the peptide concentration $(\mathrm{mg} / \mathrm{mL})$, and $\mathrm{l}$, is the cuvette path length $(\mathrm{cm})$.

\section{Radiolabeling}

Peptides $(20-40 \mu \mathrm{g})$ were radiolabeled with iodine-125 $\left({ }^{125} \mathrm{I}\right.$; Perkin Elmer, Waltham, MA) as previously described [9]. Briefly, 2 mCi of ${ }^{125} \mathrm{I}$ in buffered sodium phosphate $\mathrm{pH} 7.6$ was mixed with peptide and $20 \mu \mathrm{g}$ chloramine $\mathrm{T}$ in a volume of $10 \mu \mathrm{L}$ water for $1 \mathrm{~min}$. The reaction was quenched using $20 \mu \mathrm{g}$ sodium metabisulphite in $10 \mu \mathrm{L}$ water. Radiolabeled product was separated from free isotope by gel filtration chromatography using a Sephadex G-25 size-exclusion matrix (PD10; GE Healthcare) equilibrated with $0.1 \%$ gelatin/PBS. Fractions were collected manually and radioactivity in each measured by gamma counting after which the peak fractions were pooled. Radiochemical purity was assessed qualitatively by estimating the free radioiodide from phosphor images (Cyclone Storage Phosphor System, PerkinElmer, Shelton, CT) of SDS-PAGE gels.

\section{Animal model}

A transgenic murine model of systemic AA amyloidosis was used for this study [13]. The H2-L ${ }^{\mathrm{d}}$-huIL-6 Tg Balb/c transgenic mice (H2/IL-6 mice) constitutively express the human interleukin-6 (IL-6) transgene resulting in a chronic inflammatory state and hepatic production of serum amyloid protein A. Amyloidosis was induced in these mice by intravenous (IV) injection of $10 \mu \mathrm{g}$ of purified, splenic AA amyloid (amyloid enhancing factor, [14]) suspended in $100 \mu \mathrm{L}$ of sterile phosphate-buffered saline (PBS; pH 7.4). Biodistribution and imaging studies were performed at 4-6 wk post-induction of amyloid at which point a significant amount was present in liver, spleen, pancreas, kidney, heart, stomach and intestines. All animal manipulation and experimental procedures were performed under the auspices of a protocol approved by the University of Tennessee Institutional Animal Care and Use Committee. The University of Tennessee Medical Center Animal Facility is a component of the University of Tennessee AAALAC-I-approved animal program.

\section{SPECT/CT imaging}

SPECT/CT imaging was performed as described previously [9]. Briefly, amyloid-free, wild type (WT) mice or amyloid-laden mice (AA) were injected with $\sim 5 \mu \mathrm{g}$ of $\left[{ }^{125} \mathrm{I}\right]{ }^{\mathrm{aqa}} \mathrm{p} 5$ or $\left[{ }^{125} \mathrm{I}\right]{ }^{\mathrm{AQA}} \mathrm{p} 5(\sim 150 \mu \mathrm{Ci})$ in the lateral tail vein. After 1, 4, or $24 \mathrm{~h}$, the mice were euthanized by an isoflurane inhalation overdose. SPECT images were acquired using an Inveon trimodality imaging platform (Siemens Preclinical Solution, Knoxville, TN, [15]). Low energy $\left({ }^{125} \mathrm{I} ; 25-45 \mathrm{keV}\right)$ gamma photons were detected at each of $60,16-\mathrm{s}$ projections with $90 \mathrm{~mm}$ of bed travel in 1.5 revolutions. A $0.5 \mathrm{~mm}$-diameter, 5-pinhole (mouse whole body) collimator was used at $30 \mathrm{~mm}$ from the center of the field of view. The image data were reconstructed using a 3D ordered subset expectation maximization (OSEM) algorithm (16 iterations, 6 subsets) and displayed onto a $88 \times 88 \times 244$ matrix with 0.5 - $\mathrm{mm}$ isotropic voxels. Zoom and $\beta$ values of 1 were used.

$\mathrm{CT}$ data were acquired using an X-ray voltage biased to $80 \mathrm{kVp}$ with a $500 \mu \mathrm{A}$ anode current with an aluminum filter with $0.5 \mathrm{~mm}$ thickness. A $240 \mathrm{~ms}$ exposure was used, and $360,1^{\circ}$ projections were collected. The data were reconstructed using an implementation of the Feldkamp filtered back-projection algorithm onto a $256 \times 256 \times 603$ matrix with isotropic $211.5 \mu \mathrm{m}$ voxels. The data were down-sampled by a bin of 4 . SPECT and CT datasets were co-registered and visualized using the Inveon Research Workplace software package (Siemens Preclinical Solution, Knoxville, TN).

\section{Biodistribution}

Following image acquisition, a necropsy was performed to collect samples from 10 tissues (muscle, liver, pancreas, spleen, left and right kidneys, stomach, upper and lower intestines and heart). A small piece of each tissue was weighed in tared vials and radioactivity quantified using an automated gamma counter (1480 Wizard 3 Gamma Counter, Perkin Elmer). The tissue radioactivity data were expressed as \% injected dose per gram of tissue (\%ID/g). An additional sample of each tissue was fixed in buffered formalin for microautoradiographic studies.

\section{Microautoradiography and Congo red tissue staining}

Six-micrometre-thick tissue sections were cut from formalin-fixed, paraffin-embedded material for microautoradiography. Sections were placed on Plus microscope slides (Fisher Scientific), dipped in NTB-2 emulsion (Eastman Kodak) and stored in the dark for 4 days. Thereafter, the emulsion was developed and 
tissues counterstained with hematoxylin and eosin. For the detection of amyloid, tissue sections were stained with an alkaline Congo red solution $(0.8 \% \mathrm{w} / \mathrm{v}$ Congo red, $0.2 \% \mathrm{w} / \mathrm{v} \mathrm{KOH}, 80 \%$ ethanol) for $1 \mathrm{~h}$ at room temperature followed by counterstain with Mayer's hematoxylin for 2 min. Digital microscopic images were acquired using a Leica DM500 light microscope fitted with cross-polarizing filters (for Congo red birefringence) fitted with a cooled CCD camera (SPOT RT-slider, Diagnostic Instruments, Sterling Heights, MI).

\section{Preparation of mouse tissue extracts}

Kidney or liver tissue was harvested from WT mice at necropsy. Approximately $0.5 \mathrm{~g}$ of tissue was removed and a tenfold volume of PBS, $\mathrm{pH}$ 7.4, added. Serine protease inhibitors, leupeptin and phenylmethylsulfonyl fluoride (PMSF), were added, each at $100 \mu \mathrm{g} / \mathrm{mL}$. The solution was mixed vigorously $(3 \times 10 \mathrm{~s}$ bursts $)$ with a Polytron (Kinematica Inc., Bohemia, NY) and then centrifuged at $4000 \times g$ for $10 \mathrm{~min}$. The supernatant containing the soluble protein fraction was collected and centrifuged twice more, as above. The supernatant from the final wash was collected and sodium azide and tween- 20 were both added at $0.05 \%$.

\section{Ex vivo dehalogenation assay}

Aliquots of radioiodinated peptide were diluted 1/50 in PBS with $0.05 \%$ tween-20 (PBST). Ten microliter of this solution was added to $200 \mu \mathrm{L}$ of WT mouse tissue extract supernatants (liver or kidney) or mouse serum each prepared at $50 \% \mathrm{v} / \mathrm{v}$ in PBS. Peptide in $200 \mu \mathrm{L}$ of PBST served as a control. Samples were incubated for $1 \mathrm{~h}$ at $37{ }^{\circ} \mathrm{C}$. Five microliter of each reaction mixture were added to $7.5 \mu \mathrm{L}$ gel sample loading buffer $(4 \times$; Invitrogen, Carlsbad, CA). Samples were loaded onto 4-12\% Bis-Tris SDS-PAGE gels (Invitrogen) and electrophoresis performed for 25 min with MES buffer at $200 \mathrm{~V}$. Phospohorimaging was performed with a $2 \mathrm{~h}$ exposure to visualize the bands in the gel.

\section{Statistics}

Analysis of biodistribution data in WT mice was performed using a 2-way ANOVA with a Tukey correction for multiple comparisons and a family-wise significance level of $p=0.05$. Analyses were performed using the Prism software package (v. 6.07 or greater; GraphPad Software Inc., La Jolla, CA).

\section{Results}

\section{Peptide characterization}

Analytical RP-HPLC revealed that, following purification, each peptide migrated as a single peak, with a retention time of $\sim 9 \mathrm{~min}$, indicating a lack of significant impurities (Additional file 1: Figure S1). A trailing shoulder was evident in each chromatogram; however, this represented $\sim 10 \%$ of the total area under the curve.

Circular dichroism revealed that the peptides, suspended in water at $0.05 \mathrm{mg} / \mathrm{mL}$, adopted a predominantly coil structure with a minima/maxima at $\sim 202 \mathrm{~nm}$ and no evident minima at $222 \mathrm{~nm}$ (Fig. 1a). Upon titration of low molecular weight heparin, up to $1.5 \mathrm{mg}$, minima/maxima at $222 \mathrm{~nm}$ were observed, indicative of the formation of helical structure (Fig. 1a). Evaluation of the transition in mean residue ellipticity at $222 \mathrm{~nm}$ yielded half maximal values of $0.33 \mathrm{mg}, 0.15 \mathrm{mg}$ and $0.19 \mathrm{mg}$ for ${ }^{\mathrm{aqa}} \mathrm{p} 5,{ }^{\mathrm{AQA}} \mathrm{p} 5$ (D) and ${ }^{\mathrm{AQA}} \mathrm{p} 5$, respectively (Fig. 1b).

\section{In vivo distribution of peptides ${ }^{\mathrm{AQA}} \mathrm{p} 5(\mathrm{~d}),{ }^{\mathrm{aqa}} \mathrm{p} 5$ and ${ }^{\mathrm{AQA}} \mathrm{p} 5$ in WT mice}

To examine the in vivo dehalogenation of the three peptides, they were radiolabeled and injected into healthy wild type (WT) mice that contain no target amyloid. The three peptides were readily radiolabeled and, after purification, were deemed to be $>90 \%$ pure based on analysis of the phosphorimaging (data not shown). The biodistribution of radioiodinated peptides ${ }^{\mathrm{AQA}} \mathrm{p} 5_{(\mathrm{D})},{ }^{\mathrm{aqa}} \mathrm{p} 5$ and ${ }^{\mathrm{AQA}} \mathrm{p} 5$ in vivo was initially examined in healthy, amyloidfree WT mice at 1,4 and $24 \mathrm{~h}$ post injection (Fig. 2). At $1 \mathrm{~h}$, tissue uptake was dominated by the liver, kidneys and stomach (Fig. 2a). Both $\left[{ }^{125} \mathrm{I}\right]^{\mathrm{AQA}} \mathrm{p} 5_{(\mathrm{D})}$ and $\left[{ }^{125} \mathrm{I}\right]^{\mathrm{aqa}} \mathrm{p} 5$ had threefold greater retention in the liver, as compared to $\left[{ }^{125} \mathrm{I}\right]^{\mathrm{AQA}} \mathrm{p} 5$; however, this difference did not achieve statistical significance. In the kidneys, we observed significantly greater amounts of radiolabeled ${ }^{\mathrm{AQA}} \mathrm{p} 5$ (D) $(\sim 45 \% \mathrm{ID} / \mathrm{g})$ and ${ }^{\mathrm{aqa}} \mathrm{p} 5(\sim 39 \% \mathrm{ID} / \mathrm{g})$ as compared to $\left[{ }^{125} \mathrm{I}\right]^{\mathrm{AQA}} \mathrm{p} 5(9 \% \mathrm{ID} / \mathrm{g})$.

In contrast, there was significantly more radioiodide in the stomach of mice administered $\left[{ }^{125} \mathrm{I}\right]^{\mathrm{AQA}} \mathrm{p} 5$ $(30.7 \% \mathrm{ID} / \mathrm{g})$ relative to $\left.\left[{ }^{125} \mathrm{I}\right]\right]^{\mathrm{AQA}} \mathrm{p} 5_{(\mathrm{D})}$ and $\left[{ }^{125} \mathrm{I}\right]^{\mathrm{aqa}} \mathrm{p} 5$, where only $\sim 1 \% \mathrm{ID} / \mathrm{g}$ was observed in each case $(p<0.0001)$. This is indicative of the accumulation of free radioiodide liberated during catabolism of peptide $\left[{ }^{125} \mathrm{I}\right]^{\mathrm{AQA}} \mathrm{p} 5$ but not $\left[{ }^{125} \mathrm{I}\right]^{\mathrm{AQA}} \mathrm{p} 5_{(\mathrm{D})}$ or $\left.\left[{ }^{125} \mathrm{I}\right]\right]^{\mathrm{aqa}} \mathrm{p} 5$. At 4 and $24 \mathrm{~h}$ (Fig. 2b, c), the levels of radioactivity in all organs of mice administered $\left.\left[{ }^{125} \mathrm{I}\right]\right]^{\text {aqa }} \mathrm{p} 5$ and $\left[{ }^{125} \mathrm{I}\right]^{\mathrm{AQA}} \mathrm{p} 5 \mathrm{had}$ decreased. They decreased further at $24 \mathrm{~h}$ post injection, such that all values were $<0.5 \% \mathrm{ID} / \mathrm{g}$ (Fig. 1c). This differed dramatically from the mice receiving $\left[{ }^{125} \mathrm{I}\right]^{\mathrm{AQA}} \mathrm{p} 5$ (D) in whom the liver $(\sim 9 \% \mathrm{ID} / \mathrm{g})$ and kidneys $(\sim 40 \% \mathrm{ID} / \mathrm{g})$ retained significantly higher levels of radioactivity (Fig. 2c).

Since biodistribution measurements revealed that the significant differences in radiotracer retention in WT mice were in the liver and kidneys, microautoradiography of these tissues was used to visualize the microdistribution of each of the peptides at 1,4 and $24 \mathrm{~h}$ post 


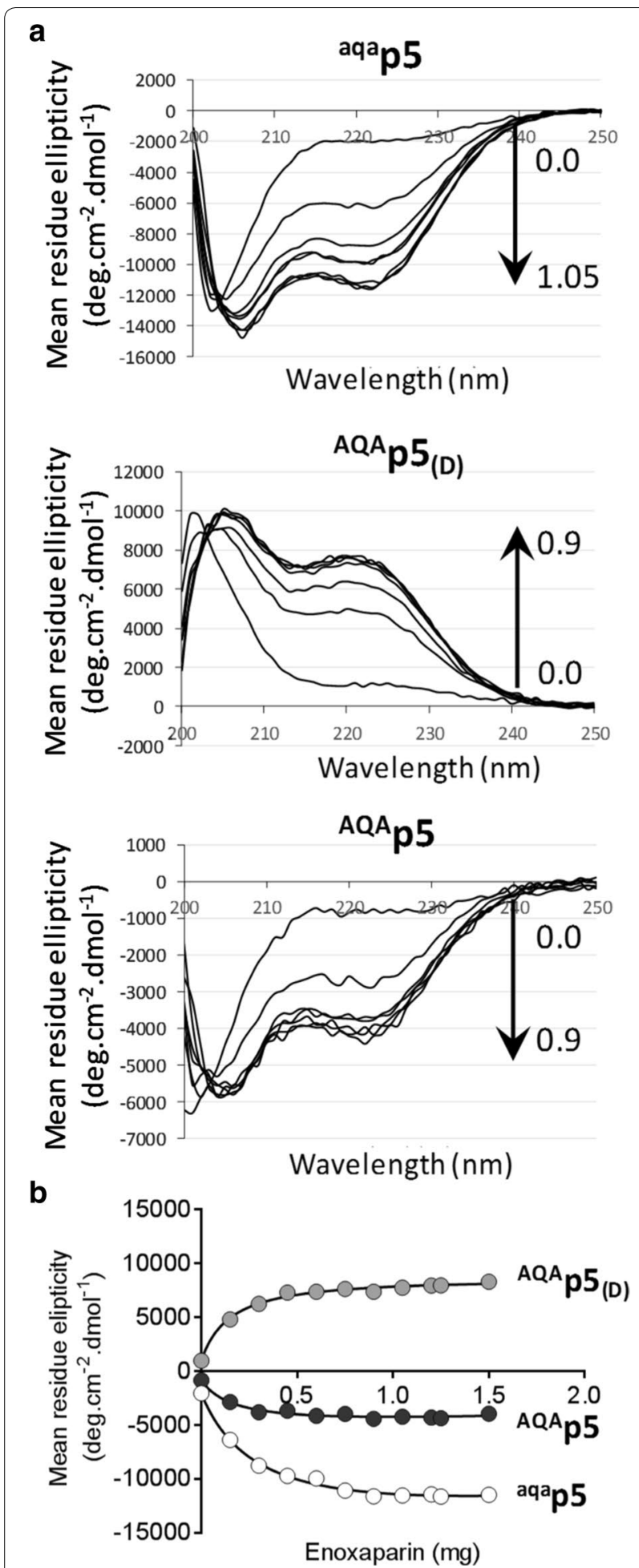

Fig. 1 Peptides exhibit an a-helical secondary structure. a Circular dichroism spectra of peptides ${ }^{\mathrm{aqa}} \mathrm{p} 5,{ }^{\mathrm{AQA}} \mathrm{p} 5_{(\mathrm{D})}$ and ${ }^{\mathrm{AQA}} \mathrm{p} 5$ adopt a helical secondary structure in the presence of low molecular weight heparin as evidenced by the change in mean residue ellipticity at $222 \mathrm{~nm}$. b The heparin-mediated change in ellipticity at $222 \mathrm{~nm}$ yielded midpoints of $0.33,0.15$, and 0.19 mg for peptides ${ }^{\text {aqa }} \mathrm{p} 5$, ${ }^{A Q A} p 5_{(D)}$ and ${ }^{A Q A} p 5$, respectively injection. Radiolabeled peptide was evidenced in the microautoradiographs by the presence of black silver grains (Fig. 3). Consistent with our tissue biodistribution data of $\left[{ }^{125} \mathrm{I}\right]^{\mathrm{AQA}} \mathrm{p} 5_{(\mathrm{D})}$, radioactivity was observed as punctate deposits throughout the WT mouse liver and did not appear to diminish over the $24 \mathrm{~h}$ post injection (Fig. 3a). Similarly, in the kidney of these mice, dense, focal radioactivity deposits were observed exclusively within the renal cortex at $1 \mathrm{~h}$ post injection and persisted for $24 \mathrm{~h}$ (Fig. 3a). The distribution of $\left[{ }^{125} \mathrm{I}\right]{ }^{\mathrm{aqa}} \mathrm{p} 5$ in the liver was, in contrast, diffuse and barely visible microscopically when viewed at low magnifications, even at $1 \mathrm{~h}$ post injection (Fig. 3b). In the kidney, radioactivity was observed to be less dense, as compared to mice receiving $\left[{ }^{125} \mathrm{I}\right]^{\mathrm{AQA}} \mathrm{p} 5_{(\mathrm{D})}$, and distributed both in the renal cortex and medulla. The radioactivity was associated with Bowman's space (arrows) as well as renal proximal tubules. The intensity of the signal decreased rapidly, and by $24 \mathrm{~h}$ post injection, only a diffuse, uniform distribution was visible throughout the kidney (Fig. 3b). The microdistribution of radioactivity in the mice that received $\left[{ }^{125} \mathrm{I}\right]{ }^{\mathrm{AQA}} \mathrm{p} 5$ (Fig. 3c) was similar to that for $\left[{ }^{125} \mathrm{I}\right]{ }^{\mathrm{aqa}} \mathrm{p} 5$; however, the presence of silver grains was greatly diminished in the liver and kidney, even at $1 \mathrm{~h}$ post injection (Fig. 3c).

In vitro dehalogenation To assess whether dehalogenation of peptides was associated with a soluble enzyme in the liver or kidney, each peptide was incubated in supernatants prepared from these organs, as well as serum, and the liberation of free radioiodide monitored by gel electrophoresis. After $1 \mathrm{~h}$ incubation, no free iodide was detected in any peptide sample under any conditions (data not shown). This indicates that in vivo dehalogenation of these peptides is a complex process, possibly involving membrane bound enzymes.

\section{SPECT/CT imaging of peptides ${ }^{\text {aqa }} \mathrm{p} 5$ and ${ }^{A Q A} p 5$ in AA and WT mice}

Radioiodinated peptide ${ }^{\mathrm{AQA}} \mathrm{p} 5_{(\mathrm{D})}$ exhibited significant binding to healthy, amyloid-free tissues in WT mice and is, thus, not useful as an agent for specifically targeting amyloid. The remaining two peptides, $\left[{ }^{125} \mathrm{I}\right]{ }^{\text {aqa }} \mathrm{p} 5$ and $\left[{ }^{125} \mathrm{I}\right]{ }^{\mathrm{AQA}} \mathrm{p} 5$, were evaluated for specific amyloid reactivity in mice with AA-associated amyloidosis (Fig. 4). Small animal SPECT/CT imaging of $\left[{ }^{125} \mathrm{I}\right]{ }^{\text {aqa }} \mathrm{p} 5$ and $\left[{ }^{125} \mathrm{I}\right]^{\mathrm{AQA}} \mathrm{p} 5$ in AA mice at 1,4 , and $24 \mathrm{~h}$ revealed accumulation of the radiotracter in abdominal organs associated with amyloid deposition in this mouse model-notably, the liver $(\mathrm{L})$, spleen $(\mathrm{Sp})$, pancreas $(\mathrm{P})$, and intestines (I). There was no evidence of radioactivity in the stomach $(\mathrm{St})$ of mice administered $\left[{ }^{125} \mathrm{I}\right]{ }^{\text {aqa }} \mathrm{p} 5$ (Fig. 4a), supporting the hypothesis that $\left[{ }^{125} \mathrm{I}\right]{ }^{\mathrm{aqa} a} \mathrm{p} 5$ is not significantly dehalogenated. Qualitative comparison of the signal intensity of the SPECT images of $\left[{ }^{125} \mathrm{I}\right]^{\mathrm{aqa}} \mathrm{p} 5$ and $\left[{ }^{125} \mathrm{I}\right]^{\mathrm{AQA}} \mathrm{p} 5$ 


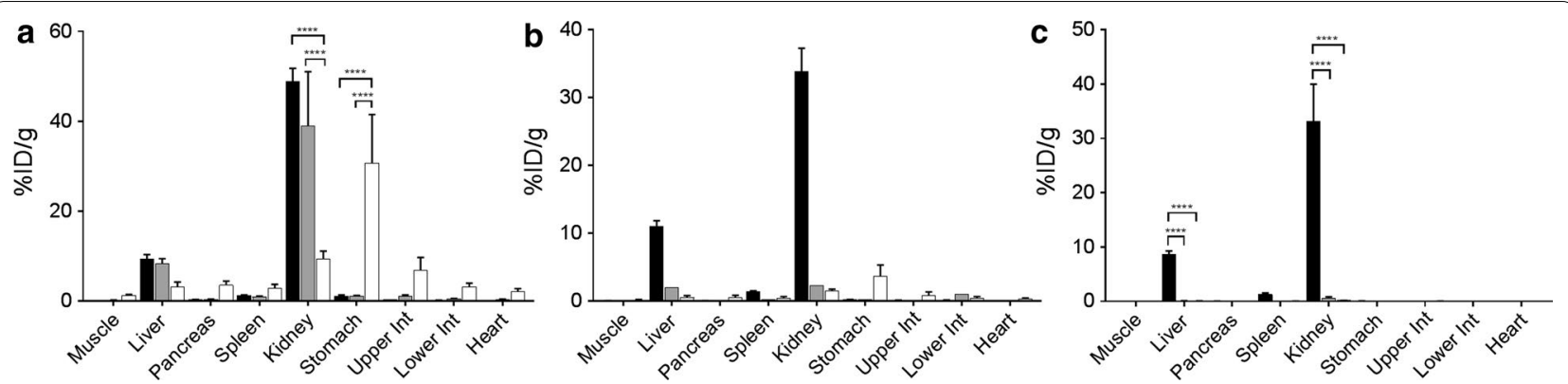

Fig. 2 Biodistribution of radiolabeled peptide in healthy WT mice. The tissue distribution, expressed as percent inject dose per gram (\%ID/g) of tissue, of radioiodinated peptides ${ }^{A Q A}{ }^{\mathrm{p} 5}$ (D), ${ }^{\text {aqa }} \mathrm{p} 5$ and ${ }^{\mathrm{AQA}} \mathrm{p} 5$ was determined in WT mice by measuring tissue radioactivity at $1 \mathrm{~h}(\mathbf{a}), 4 \mathrm{~h}$ (b) and $24 \mathrm{~h}$ (c) post injection. The data are expressed as mean \pm SD $(n=3)$ and were analyzed using ANOVA with multiple comparisons (**** $p<0.0001)$

(Fig. 4b) suggests that ${ }^{\mathrm{aqa}} \mathrm{p} 5$ was retained, particularly by the liver, in greater amounts and persisted longer than ${ }^{\mathrm{AQA}} \mathrm{p} 5$; however, the amount of amyloid in each of these mice may have been different. In the mice receiving $\left[{ }^{125} \mathrm{I}\right]{ }^{\mathrm{AQA}} \mathrm{p} 5$, radioactivity was detected in the thyroid $(\mathrm{T})$ at 4 and $24 \mathrm{~h}$ post injection (Fig. $4 \mathrm{~b}$ ) - this was less evident in mice administered $\left[{ }^{125} \mathrm{I}\right]^{\text {aqa }}$ p5 (Fig. 4a).

Imaging of $\left[{ }^{125} \mathrm{I}\right]{ }^{\text {aqa }} \mathrm{p} 5$ in WT mice showed diffuse and concentrated accumulation of the radiotracer in the liver (L) and kidney (K), respectively, at $1 \mathrm{~h}$ post injection. At 4 and $24 \mathrm{~h}$ post injection, only sparse intestinal radioactivity was observed in these mice (Fig. 4a). In contrast, the stomach (St) and thyroid ( $\mathrm{T}$ ) were the major sites of radioactivity at $1 \mathrm{~h}$ post injection in mice receiving $\left[{ }^{125} \mathrm{I}\right]{ }^{\mathrm{AQA}} \mathrm{p} 5$ (Fig. 4b). In these mice, the stomach activity was lost over $24 \mathrm{~h}$, whereas the thyroid radioactivity persisted. At $24 \mathrm{~h}$ post injection, with the exception of the thyroid, there was no evidence of binding, by SPECT imaging, of $\left[{ }^{125} \mathrm{I}\right]{ }^{\mathrm{aqa}} \mathrm{p} 5$ or $\left[{ }^{125} \mathrm{I}\right]{ }^{\mathrm{AQA}} \mathrm{p} 5$ to healthy organs or tissues (Fig. 4).

\section{Microautoradiography of $\left[{ }^{125} \mathrm{I}\right]^{\text {aqa }} \mathrm{p} 5$ and $\left[{ }^{125} \mathrm{I}\right]^{\mathrm{AQA}} \mathrm{p5}$ in AA-laden tissue}

To confirm specific binding of peptides $\left[{ }^{125} \mathrm{I}\right]^{\text {aqa }} \mathrm{p} 5$ and $\left[{ }^{125} \mathrm{I}\right]{ }^{\mathrm{AQA}} \mathrm{p} 5$ to amyloid deposits in the organs, microautoradiographic analysis of the spleen, liver, intestine and pancreas was performed. The distribution of black silver grains, representing the presence of $\left[{ }^{125} \mathrm{I}\right]{ }^{\mathrm{aqa}} \mathrm{p} 5$ (Fig. 5a) and $\left[{ }^{125} \mathrm{I}\right]^{\mathrm{AQA}} \mathrm{p} 5$ (Fig. 5b), was compared to the amyloid distribution, evidenced by the green-gold birefringence in Congo red-stained tissue sections (Fig. 5c). Representative tissue sections are shown to provide patterns of amyloid distribution in these organs (Fig. 5c). The microdistribution of $\left[{ }^{125} \mathrm{I}\right]^{\mathrm{aqa}} \mathrm{p} 5$ in the spleen, liver, intestine, and pancreas (Fig. 5a) was discrete and consistent with the pattern of amyloid distribution. Similarly, the distribution of $\left[{ }^{125} \mathrm{I}\right]{ }^{\mathrm{AQA}} \mathrm{p} 5$ was consistent with amyloid binding (Fig. 5b), although to a lesser extent as compared to $\left.{ }^{[25} \mathrm{I}\right]{ }^{\text {aqa }} \mathrm{p} 5$ given that the silver deposits were less dense, notably in the spleen and pancreas.

\section{Discussion}

To date, our studies of amyloid-reactive peptides in vivo have focused almost exclusively on variants that are radioiodinated via the L-tyrosine residue at position 4 . These peptides are susceptible to catabolic dehalogenation in the liver and kidney $[16,17]$ that can complicate interpretation of the peptide biodistribution data. However, during these studies, we have recognized that dehalogenation of unbound peptide can be exploited in medical imaging for specific detection of renal and hepatic amyloidosis when image data are collected at later time points post injection [8]. Nevertheless, we now seek to exploit these peptides for treatment of amyloidosis, and incorporation of $\mathrm{D}$-amino acids for the enhancement of in vivo stability and lifetime in the circulation may be useful if amyloid-specific reactivity can be maintained.

Incorporation of non-natural, D-amino acids into synthetic peptides has been shown to render them more resistant to proteolysis and vascular clearance in vivo as compared to their L-amino acid counterparts [18-20]. Increased bioavailability, a valuable asset for peptide therapeutics, is one advantage of extending the vascular half-life of peptides. The peptidomimetic bradykinin antagonist Icatibant ${ }^{\mathrm{TM}}$ incorporates $\mathrm{D}$-amino acids to inhibit proteolytic digestion, and it is approved for the treatment of hereditary angioedema [21]. Additionally, a retro-inverso peptide inhibitor of $A \beta$ aggregation exhibits a prolonged half-life and enhanced inhibitory efficacy as compared to the L-amino acid homolog $[19,22]$. However, placement of $\mathrm{D}$-amino acids in a bioactive peptide is critical to ensure that binding specificity and bioactivity is not jeopardized. Inappropriate substitution of D-amino acids in the center of an antimicrobial peptide sequence resulted in a complete loss of activity [23]. Nonetheless, incorporation of $\mathrm{D}$-amino acids that flank the "active" site can be advantageous [24].

Our previous evaluation of the all D-amino acid peptide, $\mathrm{p} 5_{(\mathrm{D})}$, in amyloid-free mice demonstrated that, despite retaining excellent amyloid-reactivity in in vitro 


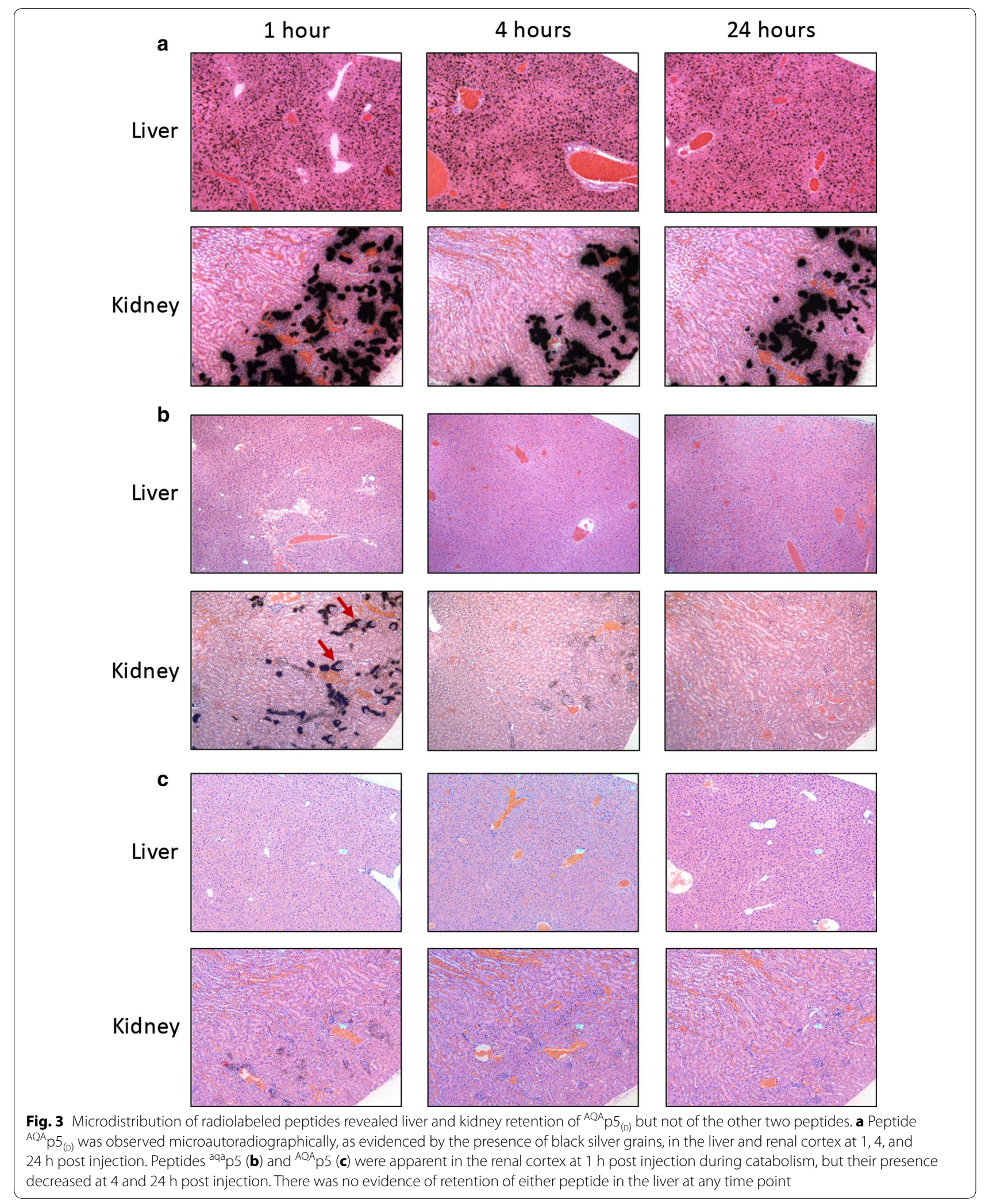




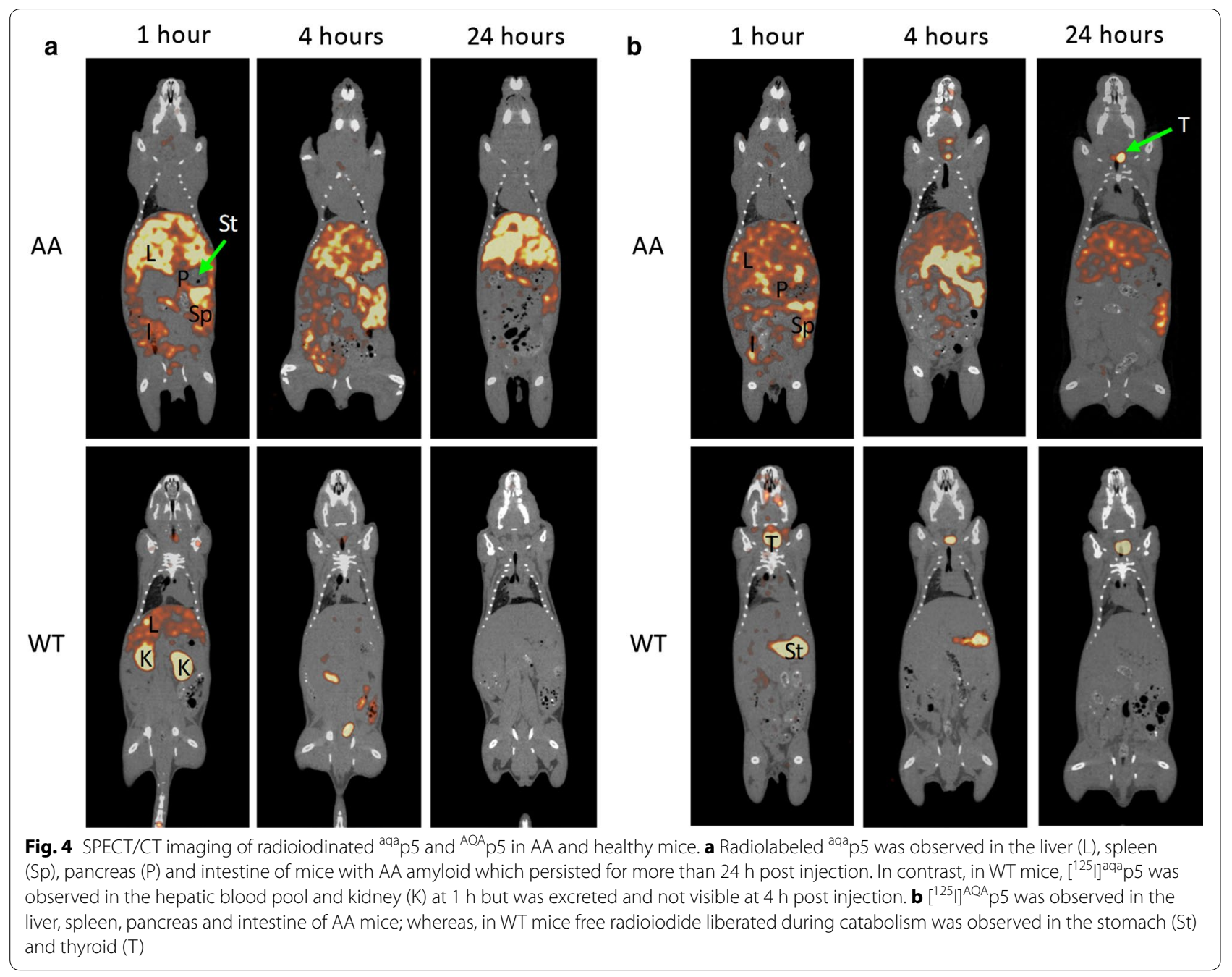

assays, the peptide bound to amyloid-free tubules in the renal cortex (but not the glomerulae) and a diffuse ligand throughout the liver [10]. Binding at these sites persisted for at least $24 \mathrm{~h}$ post injection, indicating that the all D-enantiomer variant of the amyloidophilic peptide $\mathrm{p} 5$ was unsuitable for specific amyloid-targeting in vivo.

To further probe the effect of D-amino acids in homologs of peptide p5, a novel tripeptide Ala-Gln-Ala was substituted for Gly-Gly-Gly- to facilitate assessment of $\mathrm{D}$-amino acids at the $\mathrm{N}$-terminal, which has been reported to be beneficial [25]. Since there is no D-enantiomer of glycine, Ala-Gln-Ala, which constitutes the spacing motif within the heptad repeat of peptide $\mathrm{p} 5$, was used at the $\mathrm{N}$-terminal and, thus, maintained consistency of the amino acid sequence. Incorporation of D-amino acids at the $\mathrm{N}$-terminal has been shown to enhance electrostatic stability of helical peptides [26] and increase the helicity of peptides composed of amino acids with an intrinsic propensity for helical structure in aqueous milieu [27]. The increased propensity to form an alpha helix in amyloid-reactive, polybasic peptides has been shown to enhance the affinity for amyloid deposits in vivo [12].

Using an N-terminal Ala-Gln-Ala composed of D-amino acids, peptide aqa 5 was mostly resistant to dehalogenation, as evidenced by the lack of radioiodide in the stomach, even though the Tyr residue remained an L-enantiomer (Fig. 2). Thus, the presence of D-amino acids on the $\mathrm{N}$-terminal side of the L-iodotyrosine largely prevented dehalogenation of the peptide by deiodinases in the liver and kidney. Based on these data, we speculate that murine deiodinases require $\mathrm{L}$-amino acids adjacent to the iodotyrosine during enzymatic dehalogenation for activity. Thus, juxtaposed D-enantiomers may sterically hinder the interaction between the deiodinase active site and the L-iodotyrosine. Since this peptide is mostly resistant to dehalogenation, it can be effectively tracked in vivo. These data provide the first indication that this 


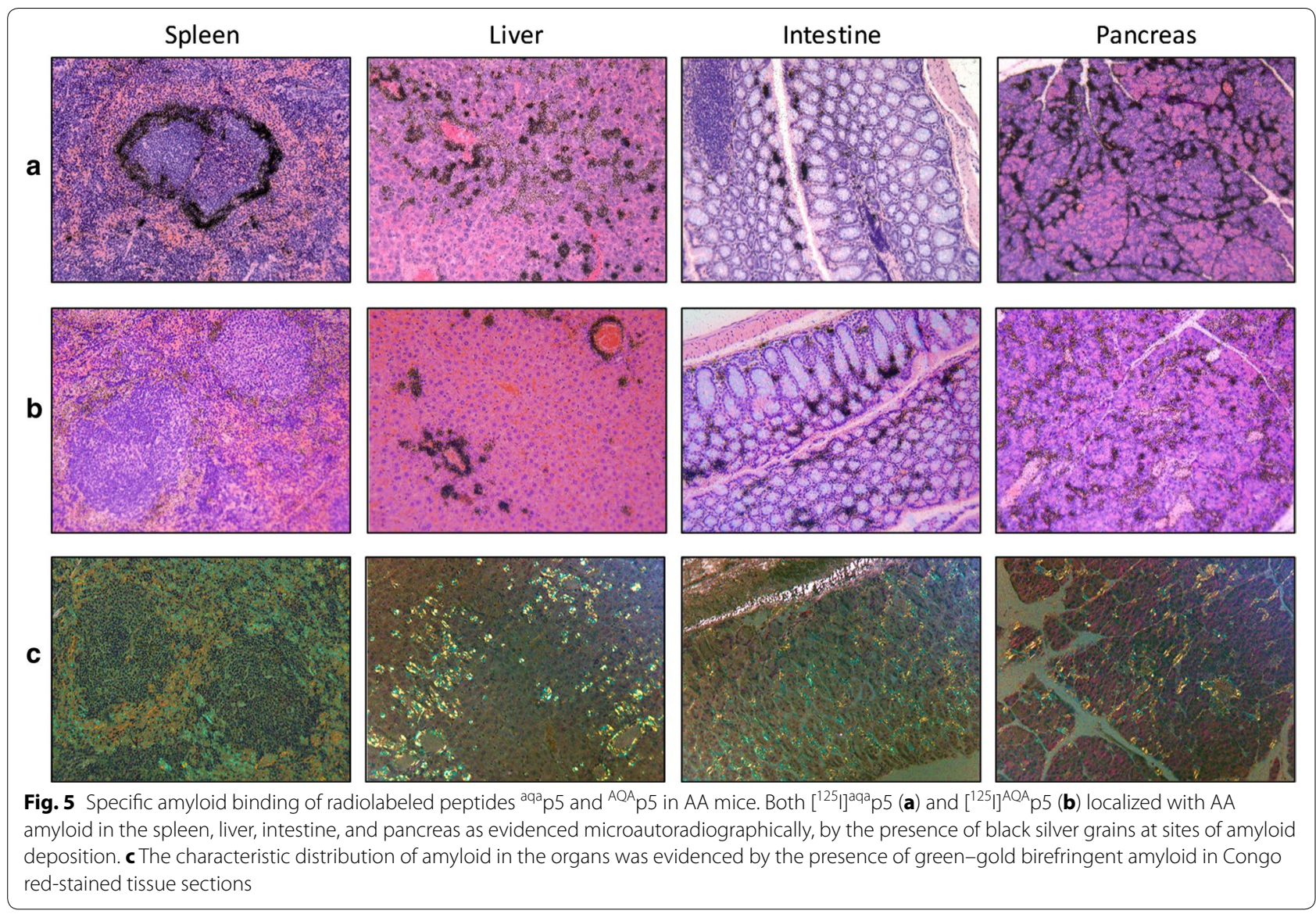

class of polybasic $\alpha$-helical peptides, which includes $\mathrm{p} 5$ $[8,12]$ and $p 5+14$ [9], does not bind intracellular ligands along the catabolic pathway within the renal proximal tubule or hepatobiliary system. Furthermore, $\left[{ }^{125} \mathrm{I}\right]^{\text {aqa }} \mathrm{p} 5$ retained specific amyloid-binding in mice with severe systemic AA-associated amyloidosis, such that amyloid in the liver, spleen, pancreas and intestine was readily detected by SPECT imaging and microautoradiography at least $24 \mathrm{~h}$ post injection. Despite the previously reported beneficial effect of peptide dehalogenation in amyloid imaging by peptides $\mathrm{p} 5$ and $\mathrm{p} 5+14[8,9]$, in the case of peptide ${ }^{\text {aqa }} \mathrm{p} 5$, resistance to dehalogenation could be advantageous particularly for the detection of gastric or pancreatic amyloid due to the absence of free radioiodide sequestered by the stomach. Therefore, radioiodinated peptide ${ }^{\text {aqa }} \mathrm{p} 5$, or a similar reagent, could provide a novel tool for imaging amyloid deposits in the kidney, pancreas and stomach.

Comparison of biodistribution of the halogen-retaining peptides ${ }^{\mathrm{AQA}} \mathrm{p} 5$ (D) and ${ }^{\mathrm{aqa}} \mathrm{p} 5$ in healthy WT mice demonstrated gross differences. Peptide $\left[{ }^{125} \mathrm{I}\right]^{\mathrm{AQA}} \mathrm{p} 5_{(\mathrm{D})}$ was resistant to dehalogenation due to the incorporation of a D-Tyr at position four. This peptide was sequestered rapidly by kidney and liver and was retained there for at least $24 \mathrm{~h}$ (Figs. 1, 2). This is consistent with the biodistribution of the all $\mathrm{D}$-amino acid peptide, $\mathrm{p} 5_{(\mathrm{D})}$, and suggests that $\mathrm{D}$-amino acid incorporation in the amyloid-binding heptad repeat region is responsible for the off-target reactivity in vivo. Although the precise nature of the ligand recognized by both ${ }^{\mathrm{AQA}} \mathrm{p} 5_{(\mathrm{D})}$ and $\mathrm{p} 5_{(\mathrm{D})}$ in healthy, amyloid-free tissue remains uncharacterized, it is possible that the ligand is a sulfated, membrane surfacebound proteoglycan, such as heparan sulfate proteoglycan. The distribution is reminiscent of $\left[{ }^{125} \mathrm{I}\right]$-labeled basic fibroblast growth factor (bFGF), particularly within the sinusoids of the liver [28]. Although, in the kidneys, $\left[{ }^{125} \mathrm{I}\right] \mathrm{bFGF}$ bound avidly to glomerular tufts rather than the proximal tubules as seen in mice administered $\left[{ }^{125} \mathrm{I}\right]^{\mathrm{AQA}} \mathrm{p} 5_{(\mathrm{D})}$. In contrast, $\left[{ }^{125} \mathrm{I}\right]{ }^{\mathrm{aqa}} \mathrm{p} 5$ was not retained in the liver or kidney at 4 and $24 \mathrm{~h}$ post-injection.

The all L-amino acid peptide, ${ }^{\mathrm{AQA}} \mathrm{p} 5$, also exhibited specific amyloid-binding capabilities, albeit with qualitatively less radiotracer uptake in the liver and spleen as compared to $\left[{ }^{125} \mathrm{I}\right]{ }^{\mathrm{aqa}} \mathrm{p} 5$. However, this cannot be attributed with certainty to a single phenomenon since this peptide is prone to dehalogenation, and the AA mice 
used in this study may have had differences in amyloid load.

\section{Conclusions}

We have studied the effects of $\mathrm{D}$-amino acid placement in amyloid-reactive peptides in anticipation that this strategy might be useful to enhance the proteolytic stability and enhance the biological half-life of peptide variants for use in novel immunotherapy strategies. Our findings indicate that: (1) complete incorporation of D-amino acids in the amyloid-binding heptad repeat caused loss of amyloid-binding specificity in vivo due to competitive retention in the liver and kidneys-sites of peptide catabolism. (2) In contrast, placement of D-enantiomers at the peptide $\mathrm{N}$-terminus did not inhibit amyloidbinding specificity. (3) This placement of D-amino acids provided resistance against the activity of deiodinases. Thus, appropriate placement of D-amino acids, e.g., at the $\mathrm{N}$-terminus, could provide a reagent $\left({ }^{\mathrm{aqa}} \mathrm{p} 5\right)$ with enhanced in vivo stability and resistance to dehalogenation. Such a reagent may serve as not only a potential candidate for amyloid immunotherapy strategies but also as a novel candidate for amyloid imaging with specific advantages for the detection of gastric, renal, or pancreatic amyloid.

\section{Additional file}

Additional file 1: Figure S1. Purified peptides appeared, by RP-HPLC chromatography, as a single peak with a retention time of $\sim 9 \mathrm{~min}$

\section{Abbreviations}

AA: serum amyloid protein A-associated amyloidosis; $\left[{ }^{[25}\right.$ ]]: iodine-125; SPECT/ $\mathrm{CT}$ : single photon emission computed tomography/X-ray computed tomography; ARG: microautoradiography.

\section{Authors' contributions}

EBM, JSW and SJK designed the experiments. AW, TR, CW, AS and EBM performed the experiments. EBM, JSF, SJK and JSW wrote and edited the manuscript. All authors read and approved the final manuscript.

\section{Author details}

${ }^{1}$ Department of Medicine, University of Tennessee Medical Center, 1924 Alcoa Hwy, Knoxville, TN 37920, USA. ${ }^{2}$ Department of Radiology, University of Tennessee Medical Center, 1924 Alcoa Hwy, Knoxville, TN 37920, USA.

\section{Acknowledgements}

We thank Jim Wesley for his assistance with tissue processing and microautoradiography.

\section{Competing interests}

SJK and JSW have patent rights associated with the use of peptides for amyloid imaging. SJK, EBM, TR, AS and JSW are co-owners of a company that has licensed intellectual property associated with the use of peptides for amyloid imaging. The other authors declare they have no competing interests.

\section{Availability of data and materials}

All datasets used and/or analyzed during the current study are available from the corresponding author on reasonable request.
Consent for publication

Not applicable.

\section{Ethics approval and consent to participate}

All animal manipulation and experimental procedures were performed under the auspices of a protocol approved by the University of Tennessee Institutional Animal Care and Use Committee. The University of Tennessee Medical Center Animal Facility is a component of the University of Tennessee AAALACl-approved animal program.

\section{Funding}

This work was supported by PHS grant R01DK079984 from The National Institute of Diabetes and Digestive and Kidney Diseases (NIDDK) and by a grant from the Physicians' Medical Education and Research Foundation in Knoxville, TN. The Molecular Imaging and Translational Research Program and the Department of Medicine at UTMC also contributed funds.

\section{Publisher's Note}

Springer Nature remains neutral with regard to jurisdictional claims in published maps and institutional affiliations.

Received: 22 August 2017 Accepted: 25 November 2017

Published online: 11 December 2017

\section{References}

1. Blancas-Mejia LM, Ramirez-Alvarado M. Systemic amyloidoses. Annu Rev Biochem. 2013;82:745-74

2. Sipe JD, Benson MD, Buxbaum JN, Ikeda S, Merlini G, Saraiva MJ, Westermark P. Nomenclature 2014: amyloid fibril proteins and clinical classification of the amyloidosis. Amyloid. 2014;21:221-4.

3. Wechalekar AD, Gillmore JD, Hawkins PN. Systemic amyloidosis. Lancet. 2016;387:2641-54.

4. Lindahl B, Lindahl U. Amyloid-specific heparan sulfate from human liver and spleen. J Biol Chem. 1997;272:26091-4.

5. Dispenzieri A, Gertz MA, Buadi F. What do I need to know about immunoglobulin light chain (AL) amyloidosis? Blood Rev. 2012;26:137-54.

6. Palladini G, Merlini G. Current treatment of AL amyloidosis. Haematologica. 2009;94:1044-8

7. Chen W, Dilsizian V. Molecular imaging of amyloidosis: will the heart be the next target after the brain? Curr Cardiol Rep. 2012;14:226-33.

8. Martin EB, Kennel SJ, Richey T, Wooliver C, Osborne D, Williams A, Stuckey A, Wall JS. Dynamic PET and SPECT imaging with radioiodinated, amyloidreactive peptide $\mathrm{p} 5$ in mice: a positive role for peptide dehalogenation. Peptides. 2014:60:63-70.

9. Martin EB, Williams A, Richey T, Stuckey A, Heidel RE, Kennel SJ, Wall JS. Comparative evaluation of $\mathrm{p} 5+14$ with SAP and peptide $\mathrm{p} 5$ by dual-energy SPECT imaging of mice with AA amyloidosis. Sci Rep. 2016:6:22695

10. Wall JS, Williams A, Richey T, Stuckey A, Wooliver C, Christopher Scott J, Donnell R, Martin EB, Kennel SJ. Specific amyloid binding of polybasic peptides in vivo is retained by beta-sheet conformers but lost in the disrupted coil and all D-amino acid variants. Mol Imaging Biol. 2017:19:714-22.

11. Wall J, Williams A, Wooliver C, Martin E, Cheng X, Heidel E, Kennel SJ. Secondary structure propensity and chirality of the amyloidophilic peptide p5 and its analogues impacts ligand binding —in vitro characterization. Biochem Biophys Rep. 2016:8:89-99.

12. Wall JS, Williams A, Richey T, Stuckey A, Huang Y, Wooliver C, Macy S, Heidel E, Gupta N, Lee A, et al. A binding-site barrier affects imaging efficiency of high affinity amyloid-reactive peptide radiotracers in vivo. PLOS ONE. 2013;8:e66181.

13. Solomon A, Weiss DT, Schell M, Hrncic R, Murphy CL, Wall J, McGavin MD, Pan HJ, Kabalka GW, Paulus MJ. Transgenic mouse model of AA amyloidosis. Am J Pathol. 1999:154:1267-72.

14. Kisilevsky R. Preparation and propagation of amyloid-enhancing factor. Methods Mol Biol. 2005:299:237-41. 
15. Magota K, Kubo N, Kuge Y, Nishijima K, Zhao S, Tamaki N. Performance characterization of the Inveon preclinical small-animal PET/SPECT/ CT system for multimodality imaging. Eur J Nucl Med Mol Imaging. 2011;38:742-52.

16. Araujo RL, Carvalho DP. Bioenergetic impact of tissue-specific regulation of iodothyronine deiodinases during nutritional imbalance. J Bioenerg Biomembr. 2011:43:59-65.

17. Leonard JL, Ekenbarger DM, Frank SJ, Farwell AP, Koehrle J. Localization of type I iodothyronine $5^{\prime}$-deiodinase to the basolateral plasma membrane in renal cortical epithelial cells. J Biol Chem. 1991;266:11262-9.

18. Kumar J, Sim V. D-Amino acid-based peptide inhibitors as early or preventative therapy in Alzheimer disease. Prion. 2014;8:119-24.

19. Taylor M, Moore S, Mayes J, Parkin E, Beeg M, Canovi M, Gobbi M, Mann DM, Allsop D. Development of a proteolytically stable retro-inverso peptide inhibitor of beta-amyloid oligomerization as a potential novel treatment for Alzheimer's disease. Biochemistry. 2010;49:3261-72.

20. Zhou N, Luo Z, Luo J, Fan X, Cayabyab M, Hiraoka M, Liu D, Han X, Pesavento J, Dong CZ, et al. Exploring the stereochemistry of CXCR4peptide recognition and inhibiting HIV-1 entry with D-peptides derived from chemokines. J Biol Chem. 2002;277:17476-85.

21. Dubois EA, Cohen AF. Icatibant. Br J Clin Pharmacol. 2010;69:425-6.

22. Matharu B, El-Agnaf $O$, Razvi A, Austen BM. Development of retro-inverso peptides as anti-aggregation drugs for beta-amyloid in Alzheimer's disease. Peptides. 2010;31:1866-72.
23. Hong SY, Oh JE, Lee KH. Effect of D-amino acid substitution on the stability, the secondary structure, and the activity of membrane-active peptide. Biochem Pharmacol. 1999;58:1775-80.

24. Tugyi R, Uray K, Ivan D, Fellinger E, Perkins A, Hudecz F. Partial D-amino acid substitution: improved enzymatic stability and preserved $A b$ recognition of a MUC2 epitope peptide. Proc Natl Acad Sci USA. 2005;102:413-8.

25. Rabideau AE, Pentelute BL. A D-amino acid at the $\mathrm{N}$-terminus of a protein abrogates its degradation by the $\mathrm{N}$-end rule pathway. ACS Cent Sci. 2015;1:423-30.

26. Goyal B, Kumar A, Srivastava KR, Durani S. Scrutiny of chain-length and $\mathrm{N}$-terminal effects in alpha-helix folding: a molecular dynamics study on polyalanine peptides. J Biomol Struct Dyn. 2017;35:1923-35.

27. Goyal B, Srivastava KR, Durani S. N-terminal diproline and charge group effects on the stabilization of helical conformation in alanine-based short peptides: CD studies with water and methanol as solvent. J Pept Sci. 2017;23:431-7.

28. Wall J, Martin E, Donnell R, Richey T, Stuckey A, Kennel SJ. Heparin-binding peptides, basic fibroblast growth factor and $\mathrm{p} 5 \mathrm{R}$, bind to different targets in amyloid-laden mice and controls. In: Kluve-Beckerman B, Liepnieks J, Benson M, ed. The XIVth international symposium on amyloidosis; Indianapolis, IN, USA; 2014. p. 284-287.

\section{Submit your next manuscript to BioMed Central and we will help you at every step:}

- We accept pre-submission inquiries

- Our selector tool helps you to find the most relevant journal

- We provide round the clock customer support

- Convenient online submission

- Thorough peer review

- Inclusion in PubMed and all major indexing services

- Maximum visibility for your research

Submit your manuscript at www.biomedcentral.com/submit
() Biomed Central 